\title{
Trade Tariffs and Selected Macroeconomic Indicators of Performance in Nigeria, 1980 - 2018
}

\author{
Akeeb Olusholaoladele, Emmanuel Uzoma Makwe, Ernest Tubolayefa
}

\begin{abstract}
- this study was undertaken to examine the impact of trade tariffs on selectedmacroeconomic variables in Nigeria, 1980-2018. The researcher used three models, three dependent and three independent variables to determine the extent of this impact. Secondary data time series obtained from the CBN statistical bulletins was used. The variables considered were customs duty, balance of payments, gross domestic products (GDP), value added tax (VAT), petroleum income tax (PIT), and unemployment (UNEM) of Nigeria over the period. OLS regression methodology using the ARDL was employed as estimation technique at $5 \%$ level of significance. ADF was used to estimate the unit root tests while bounds test for co-integration analysis was used to estimate the long-run relation of the variables. Error Correction Mechanism was used to correct the short term errors of the analysis. It was shown that while some of the variables have positive and significant effects on the dependent variables, other do not. It was, therefore recommended that government authorities must properly target tariffs, value added tax (VAT) and petroleum income tax (PIT) to achieve their aims and not to indiscriminately manipulate them for no justifiable reasons.

Index Terms - Trade Tariff, Value Added Tax, Petroleum Income Tax, Custom Duties, Gross Domestic Product, Unemployment Rate.
\end{abstract}

\section{INTRODUCTION}

Economic growth and development aresustained expansion of production possibilities measured asthe increase in real Gross Domestic Product (GDP), unemployment rate, balance of payment, etc. over a given period of time(Parkin, Powell \& Matthews, 2008). The role of trade in economic growth and development is significant. Its significance is also widespread: it is a source of market for locally made goods; technology transfer among nations; income generation, etc. The Classical and Neo-classical economists attached so much importance to international trade in a country's development that they regarded it as a major 'engine of growth.' International trade increases savings and investment, reduces unemployment and under-employment, enhances greater backward and forward linkages in the economy and ensures a larger inflow of factor inputs into the economy and outflow of goods and services. Tariffs are custom or excise duties paid on imported or exported goods, for most economies, this is one of the highest income generating machines for the

Akeeb Olusholaoladele, Department Of Economics, Faculty Of Social Sciences, School Of Graduate Studies, University Of Port Harcourt

Emmanuel Uzoma Makwe, Department Of Economics, Faculty Of Social Sciences, School Of Graduate Studies, University Of Port Harcourt

Ernest Tubolayefa, Department Of Economics, Faculty Of Social Sciences, School Of Graduate Studies, University Of Port Harcourt government (Wacziarg \& Welch, 2008).

Over the past decades, the developmental role of export had been appreciated from the fact that it earns foreign exchange, increases firms' sales/profit, lowers production cost, creates employment, earns international recognition, enhances reputation, and improves the living standard of both the exporting and importing firms/nations. Exports have long played a role in the analysis of regional economies, primarily through the concept of the economic base. The need to export is predicated solely on economic reasons. Export promotion highlights on two most important concepts. Firstly, export in the context of regional economic development is seen as goods and services sold outside the region, not necessarily international. Secondly, export may refer to goods and services sold to people in countries other than the country where the product or service is produced.

Most countries control the movement of goods crossing their borders, whether leaving (exports) or entering (imports). Some of the basic export and import documents are tariffs, quotas, etc. They are barriers to the free flow of goods between independent sovereignties and are requirements that must be met by either the exporter or the importer or both. In other to ensure good trading relationship between countries and easy movement of goods, services and human capital, trade barriers are reduced or removed (Aimiumu, 2004).

Nigeria has achieved some appreciable output growth until recently when it slumped into another recession (Ugochukwu \& Azubuike, 2018). A number of explanations of this observed trend have been attempted in different academic papers. Non-oil exports performance had also improved moderately during that period. Several factors appear to have contributed to this phenomenon including a rapid improvement in trade liberalization through improved exportation, concerted efforts to diversify the productive base of the economy, and a substantial increase in foreign direct investment inflows into the country. With the political and economic changes, the balance of payment deficit reduced significantly and there was significant reduction in the unemployment rate.

However, it is noteworthy that despite the policy thrust on export promotions as well as the restructuring of the system to improve the tax (tariff) generated from international trade, there has not been any satisfactory result from the corridor in recent times - especially due to the recession era. Balance of payment deficit, increased unemployment rate and negative GDP have resurfaced. Various authors had investigated the importance of customs duty, balance of payment and employment rate differently and they came up with various results based on their methodologies. 


\section{A. Statement of the Problem}

The issue of whether tariffs, trade and increased openness of trade would lead to higher rates of economic growth and development through the reduction in deficit balance of payments, unemployment rate is an age-old debate between pro-traders and anti-traders over the years. Pro-traders of free trade have lauded the gains from trade through the specialization of countries in the production of goods in which they have comparative advantage and engage in trade and exchange to meet their other needs.

In Nigeria, tariff (tax) revenue has accounted for a small proportion of total revenue generated over the years compared with the bulk of revenue generated by the Federal Government (Out \& Adejumo, 2013). Records showed that decline in oil prices in recent times has led to decreased funds available for distribution among Federal, State and Local Governments in Nigeria (Afuberon \& Okoye, 2014). Hence, over-dependence on oil as a major source of revenue in Nigeria has become a serious set-back for sustainable economic growth due to the fact that bulk of the revenue is generated through export duties on petroleum products. The fluctuation in oil prices in the international market has been a serious concern for Nigerians and government on the need to diversify the economy.

It is noteworthy that globally, there is a paradigm shift to tax revenue as a better alternative source of revenue generation and the need for Nigerian government to generate adequate revenue from taxation has become a matter of urgency and importance (Afuberon \& Okoye, 2014). Hence, the inconsistent results of previous studies regarding the effect of tax revenue on economic growthprompts further investigationin Nigeria.

This study therefore focused on answering key questions on tariffs: 1. Is there any significant relationship between taxes (tariffs) and economic development (GDP, balance of payment (BOP and unemployment rate))? If there is none, this becomes a standpoint to remove trade tariffs and allow for free trade.

\section{B. Hypotheses}

The hypotheses for the study were stated in the null form:

1. $\mathbf{H}_{01}$ :There is no significant relationship between petroleum tax and GDP

2. $\mathbf{H}_{\mathbf{0 2}}$ : There is no significant relationship between customs duties and GDP

3. $\mathbf{H}_{\mathbf{0 3}}$ : There is no significant relationship between VAT and GDP

4. $\mathbf{H}_{04}$ :There is no significant relationship between petroleum tax and BoP

5. $\mathbf{H}_{05}$ :There is no significant relationship between customs duties and BoP

6. $\mathbf{H}_{06}$ :There is no significant relationship between VAT and $\mathrm{BoP}$

7. $\mathbf{H}_{\mathbf{0 7}}$ : There is no significant relationship between petroleum tax and unemployment rate

8. $\mathbf{H}_{\mathbf{0 8}}$ : There is no significant relationship between customs duties and unemployment rate

9. $\mathbf{H}_{\mathbf{0 9}}$ : There is no significant relationship between VAT and unemployment rate

\section{LITERATURE REVIEWS}

\section{A. Conceptual Review}

\section{Custom and Excise Duties in Nigeria}

Fasoranti, (2013) described Import duty as a levy on imports by custom authorities in Nigeria to raise revenue for the government and protect domestic industries from predator competitors abroad. Oladipupo and Ibadin (2015), stated that import duty is generally on the value of goods oron the weight, dimensions or some other criteria that are determined by the government. They are charged as a percentage of the value of import or a fixed amount of specific quantity (Fasoranti, 2013). This also applies to export duties. Import duties are either fixed or calculated as a percentage of the product's value, which can change (Olurotimi, 2013). Sometimes, government may want to protect certain domestic product from foreign competition. One way of doing so is by imposing import duty, which makes foreign products more expensive, thus keeping the same domestic products more competitive (Ilaboya, 2012). Okoye and Gbegi (2013) maintained that government sometimes, imposes duties to hurt another country by making its exports more expensive. This is usually done as a retaliatory measure in a trade war. It is based on the value of goods called ad valorem duty or the weight, dimensions, or other criteria of the item such as its size (Oladipupo\&Ibadin, 2015).

Olurotimi, (2013) asserted that export duty is levied on the goods passing through a customs area with a route to another area or country. Point of taxation will be occurring from the date of export or from the movement of transferring goods from one country to another (Okoye\&Gbegi 2013). Export duties are no longer used to a great extent, except for certain mineral, petroleum, and agricultural products. Several resource-rich countries depend on export duties for much of their revenue (Ugochukwu \& Azubike, 2015). Export duties were common in the past; however, were significant elements of mercantilist trade policies. Inyiama, Ikechukwu and Madubuko, (2016) affirmed that an excise duty is the type of tax charged on goods produced within the country (as opposed to customs duties, charged on goods from outside the country). Though the collection of excise duty augments revenue generated by the government to provide public goods and services, however, over the years it has been used as an instrument of fiscal policy to stimulate economic growth and development and reduction in the rate of unemployment (Olurotimi, 2013).

\section{Petroleum Income Tax}

The oil industry has achieved great prominence in the Nigeria economic environment since the early seventies. It is because of the importance that government attached to oil exploration and production that the taxation of profit or gains of companies engaging in such operations are taxable under a law different from the companies' income tax. The petroleum profit tax was enacted in 1959 and has been severally amended overtime. This Act dealing with the taxation of companies that are engaged in petroleum operation has long been enacted as chapter 354 of the laws of the Federal Republic of Nigeria (LFN) (1990). Petroleum operation includes petroleum exploration, development, production, 
and sale of crude oil. Thus companies that only market petroleum products including refined oil does not fall in the categories of companies engaging in petroleum operations and they are therefore taxable under the companies' income tax.

\section{Value Added Tax (VAT)}

Value added tax can be defined as the increment value which a producer, using labour, contributes to his materials or purchases before selling the processed goods and services. Here, the producer can be a manufacturer, a distributor or supplier of goods or services. In other words, the original items purchased or stock of materials must have undergone some processing or improvement to warrant any value being added to the original form or shape. The inputs are processed by labour to produce the final goods and services which are sold. Value added tax is the levy on the value added at various stages of sales that is known as VAT.

\section{Gross Domestic Products}

A nation's GDP is the total value of all final goods and services produced for the market place during the year, within the nation's borders. Abbas, Akbar, Nasir, Ullah andNaseem, (2011) observes, “A nation's GDP is calculated by adding together total consumer spending, total government spending, total business spending and the value of net exports". Gross Domestic Products is one of the essential indicators of a country's economic status or health. It is also used to gauge the living standard of a given country. Ayanwale, (2007) suggests that "Gross Domestic Products can be expressed in nominal or real terms. Nominal GDP reflects the value of all the goods and services which are produced in a country during a given period, using their prices at the time of production. Real Gross Domestic Products also reflects the value of produced goods and services, but it uses constant consumer and producer price indices to remove the effects of rising price levels (inflation). Periods of real Gross Domestic Products growth are thought to promote the welfare of people as economic growth makes it possible for average incomes to increase, which in turn translates to a greater extent of consumption. Periods of negative real Gross Domestic Products growth are associated with lower incomes, lower consumption and consequently a lower standard of living".The estimation of Gross Domestic Products can adopt a number ofapproaches. Ekweogu(2013) asserts that "the production estimate hinges on the values using three different methods; the production estimate is based on the value of final output in the economy less the inputs used up in the production process, the expenditure estimate is based on the value of total expenditure on goods and services, excluding intermediate goods and services, produced in the domestic economy during a given period, the income estimate measures the incomes earned by individuals and corporations directly from the production of outputs (goods and services).

\section{Balance of Payments}

The Current Account Balance (CAB) is a key component of the Balance of Payment (BOP) and of vital importance in macroeconomic analysis of an open economy. Current account balance measures current payments (cash outflows) and current receipts (cash inflows) between residents of a country and the rest of the world. Kariuki, (2009) explains that current account balance comprises of factor income, balance of transactions of goods and services and current transfers. Current account balance is an important economic measure of how well an economy fairs in international economic transaction and a key indicator of the level of national savings, spending behavior and investment (Wanjau, 2014). Current account covers all transactions that involve real sources (goods, services, income) and current transfers. The Current Account records exports and imports of goods and services, income receivable and payable abroad as well as current transfers.

Current Account transactions are recorded on atransactions gross basis. All credit transactions (i.e. receipts from abroad) and debit transactions (i.e. payments to abroad) arerecorded. According to Todaro andSmith, (2003), current account balance is the difference between a country's total exports and imports of goods and services, plus net investment income, debt service payments, remittances and transfers. Current account balance is said to be in deficit when there is negative balance and surplus when the balance is positive. The balance of payment identity states that the net balance on the current account should exactly reflect the net balance on the capital and financial account (International Monetary Fund, 2009). Kandil (2008) observed that the accounting relationship in the balance of payments indicates that a deficit in the current account may be associated with an increase in either the financial balance or a reduction in foreign reserves.

\section{Unemployment}

According to Salami (2013), unemployment or joblessness, as defined by the International Labour Organization (1982) occurs when people are without jobs and they have actively sought work within the past five weeks. The unemployment rate is a measure of the prevalence of unemployment and it is calculated as a percentage by dividing the number of unemployed individuals by all individuals currently in the labour force. The Newsweek (2011) reported that more than 200 million people globally are out of work, a record high, as almost two-thirds of advanced economies and half of developing countries are experiencing a slowdown in employment growth.

Dependence on jobs to make money to buy food and shelter was the beginning of unemployment (Olayiwola \& Okodua, 2007). Because it has not always been acknowledged or measured systematically, there are limited historical records on unemployment (Okodua, 2009).

Recognition of unemployment occurred slowly as economies across the world industrialized and bureaucratized. The recognition of the concept of "Unemployment" is best exemplified through the well documented historical records in England (Rekha, 2010). For example, in 16th century England no distinction was made between vagrants and the jobless as they were simply categorized as "sturdy beggars", to be punished and moved on (Business Week, 2011). An individual who cannot either join an enterprise or create a job is unemployed. As individual farmers, merchants, and artisans organize themselves into large enterprises, those who cannot join or compete favourably become unemployed (Shiro, 2009). 


\section{B. Theoretical Framework}

\section{Mercantilist Theory}

The theory states that the world only contained a fixed amount of wealth and that to increase a country's wealth; one country had to take some wealth from another, either through having a higher import/export ratio. So, this tendency, to export more and import less and to receive in exchange gold (the deficit is paid in gold) is called MERCANTILISM.

The theory was criticized by the newly appeared class. More money was associated with less products and inflation. The standard of living is weaker. Mercantilist ideas did not decline until the coming of the Industrial Revolution and of laissez-faire.

\section{Absolute Advantage Theory}

In the second half of the XVIII century, mercantilist policies became an obstacle for the economic progress. Adam Smith (father of liberalism and economical science) brought the argument in his book "The Wealth of Nations", published in 1776, that the mercantilist policies favoured producers and disadvantaged the interests of consumers.

Adam Smith's theory starts with the idea that export is profitable if you can import goods that could satisfy better the necessities of consumers instead of producing them on the internal market. The essence of Adam Smith theory is that the rule that leads the exchanges from any market, internal or external, is to determine the value of goods by measuring the labour incorporated in them. In order to demonstrate its theory, Adam Smith analysed for the beginning country A, using one factor of production, the productivity of labour, evaluated in the necessity of hours needed to produce a unit of measure of the products $\mathrm{X}$ and $\mathrm{Y}$. He used a uni-factorial system of economy. Symbolizing H-hours, L-labour, the unitary necessary of labour for product $\mathrm{X}$ is HLX and for $\mathrm{Y}$ HLY.

Because all the economies have limited resources, there are limits in the level of production, and if a country wants to produce much of one product it has to give up producing another good, existing in this case renounce of trade.

\section{Comparative Advantage}

Absolute advantage was criticised due to its limitations. These criticisms led to the neo-classicalists comparative advantage. This theory states that nations should focus more in the production of goods upon which it has comparative advantage. Illustrating this, if two countries produce A and B. Country 1 produces $\mathrm{A}=10, \mathrm{~B}=12$ while country 2 produces $A=13, B=9$. Country A should focus more on the production of A while country B should focus on the production of B. This will lead to increased world output. This study therefore is anchored on the theory of comparative advantage.

\section{Empirical Reviews}

Osman and Evans (2005) examined the short-run and long-run elasticities of the Somalian exports for banana and livestock products in Somalia. They employed co-integration and error correction within 1967 to 1987 . The results obtained provide evidence of a long-run equilibrium relationship between the Somalian exports and its major determinants. The error correction predicts the adjustment of the variables to their long-run equilibrium value reasonably well, but there is a substantial variation in the adjustment speed across commodities.

Zheng and Sayed (2012) identified the main factor influencing U.S. pistachio export demand in North America for 1989 to 2009 using descriptive and simple linear regression. Findings indicate that Canadian GDP, U.S walmut export prices, and food safety concerns explain the majority of the pistachio import demands variation in Canada, whereas Iranian pistachio export prices, the real exchange rate between the Mexican peso and the U.S. dollar, and U.S. pecan export prices explain the majority of the Mexican pistachio import demand variation.

Husein (2008) empirically estimates the critical parameters of the aggregate export demand function for Jordan within 1970 to 2004 using Johansen-Juselius and Saikkonen-Lütkepohl multivariate co-integration. The empirical results confirm that there exists a unique and significant long-run equilibrium relationship among exports, foreign income, relative export price, and domestic output. Our estimation results show that income elasticity is much larger than unity while export price elasticity is slightly above one. The long-run estimate of the export price elasticity reveal that the Marshall-Lerner condition is satisfied for Jordan and currency devaluation may be effective in improving Jordanian exports and her trade balance. Moreover, domestic output has a positive and significant impact on Jordanian exports.

Hamori and Matsubayashi (2009) used panel data to empirically analyze the stability of the export functions of Less Developing Countries within 1980 to 2004 by employing cointegration estimation. They found that the use of panel data for the region of the LDC clearly supports a cointegrating relationship. Their empirical results also show that price elasticity ranges between -0.24 and -0.34 and income elasticity ranges between 1.36 and 1.79 for the panel of LDCs.

Nanang (2010) analyzed the factors that affect the export demand for Ghana's timber products using co-integration and ECM techniques for a period of 1961 to 2006. They find that exchange rates and income were significant determinants of exported timber products and had the theoretically expected positive signs. The three policy initiatives significantly reduced the exports of sawnwood, but increased the exports of plywood and veneer. Price was moderately elastic for sawnwood and plywood and had the expected negative signs in both cases, while it was positive and inelastic for veneer. The error-correction coefficients show that $68 \%$ of shocks to veneer exported is corrected in the following year, while only approximately $20 \%$ and $19 \%$ of this are corrected for sawnwood and plywood, respectively. Sawnwood and plywood face stiff competition in the international market and this has revenue and tax policy implications for Ghana's forestry sector.

Hossain (2009) investigates the aggregate export demand behaviour in Indonesia for a period of 1963 to 2005 using Pesaran bounds testing and the Johansen co-integration tests, and long-run estimate. Pesaran bounds testing and the Johansen co-integration tests results suggest that there exists a long-run relationship between real exports, world income 
and the relative export prices in Indonesia. The long-run income elasticity of the demand for Indonesia's exports is significantly greater than one and the long-run relative export price elasticity of the demand for its exports is significantly lower than one. The recursive and rolling regressions and the Hansen-Johansen stability test results suggest that the export demand function for Indonesia has undergone a significant structural change since the late-1990s, which is reflected in the decrease of the income elasticity, and an increase in the relative export price elasticity, of demand for Indonesian exports.

Timmer and Vries (2015) analyze the impact of foreign demand on Chinese employment creation from 1995 to 2012 using Global input-output methodology. They find that between 1995 and 2001, fast growth in foreign demand was offset by strong increases in labour productivity and the net effect on employment was nil. Between 2001 and 2006, booming foreign demand added about 70 million jobs. These jobs were overriding for workers with only primary education. Since 2006 growth in domestic demand for non-tradable has become more important for job creation than foreign demand, signaling a rebalancing of the Chinese economy.

Dike (2013) investigated the external crude oil demand security risks of OPEC member states using a panel estimation technique. In assessing these risks, this study introduced two indexes. The first index, Risky Energy Exports Demand (REED), indicates the level of energy export demand security risks for OPEC members. It combines measures of export dependence, economic dependence, monopsony risk and transportation risk. The second index, Contribution to OPEC Risk Exposure (CORE), indicates the individual contribution of the OPEC members to OPEC's risk exposure. His study utilises the disaggregated index approach in measuring energy demand security risks for crude oil and natural gas and involves a country level analysis.

Woerter and Roper (2010) reconsider the role of 'home' and 'export' market demand in stimulating manufacturing innovation using comparable panel data for two small open economies - Ireland and Switzerland. They employed panel techniques using a data set of 1994 to 2005 . They found little evidence of any significant market demand effects, with innovation performance instead determined largely by firm-level capability effects and characteristics. In policy and strategy terms, they suggest the continued value of measures to improve innovation capability regardless of market demand conditions. In more methodological terms, their results suggest the validity of the usual assumption implicit in modelling innovation outputs that supply-side factors predominate.

Nadeesha and Silva (2013) evaluated the development of Sri Lankan exports over the recent past and try to highlight a relationship between exports and shipping services for Sri-Lanka within 1987-2011, using descriptive, regression (OLS) and VAR analysis. Findings show that there is strong straight line relationship between the value of exports and the amount of cargo loaded. The VAR techniques reports that the derived demand for shipping by exports can be forecasted by using export performance data over a period of time.
Senhadji and Montenegro (1998) estimated export demand elasticities for a large number of 73 developing and industrial countries using time series techniques for a period of 1960 to 1993. Empirical findings revealed that the price and income elasticity estimates have good statistical properties. More so, the average long-run price and income elasticities are found to be approximately -1 and 1.5 , respectively. Thus, exports do react to both the trade partners' income and to relative prices. Indeed, Africa faces the lowest income elasticities for its exports, while Asia has both the highest income and price elasticities.

\section{METHOD OF STUdY}

\section{A. Research Design}

Nachmias and Nachmias (1976) cited in Baridam (2001) see research design as a framework or plan that is used as a guide in collecting and analyzing data for a study. The study adopted the quasi-experimental research design. This is adopted because the study sought to explore the effect of the proxies for trade tariffs on selected macroeconomic indicators. Nwankwo (2013), has it that the quasi-experimental design allows for the evaluation of the effect of independent variable(s) on a dependent variable using time series data.

\section{B. Data Collection Methods and Sources}

The study will rely on time series secondary data covering the dependent and independent variables which will be obtained, mainly, from the CBN statistical bulletin covering the periods $1980-2018$.

\section{Method of Data Analysis}

The researcher used the descriptive statistics, unit root test, autoregressive distributed lag (ARDL), co-integration analysis and error correction mechanism to analysis the data used. Thereafter, the researcher conducted post estimation test: Ramsey Reset test to check whether or not the model is correctly specified in linear form, the Breusch-Godfrey Serial Correlation LM test to check if the model suffers autocorrelation problem in the residuals up to the specified lag order, the White's heteroskedasticity test to verify whether or not the variance of the residuals of the model are homoscedastic, the Jarque-Bera test to verify if the variables of the model are normality distributed and the CUSUM test for stability to determine whether or not the model is stable and suitable for making long run decision.

\section{Model Estimation Technique}

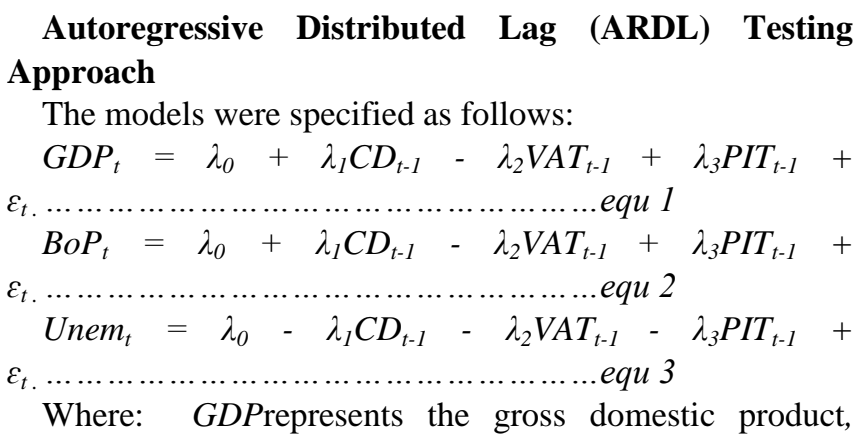

BoPrepresents balance of payments, Unemrepresents 
unemployment rate, $C D$ is the customs duty (tariff), VAT is Value added tax and PITrepresents petroleum income tax.and $\varepsilon_{t}=$ white noise error term.

$$
\text { IV. DATA ANALYSIS }
$$

\section{A. Descriptive Analysis}

\begin{tabular}{|l|c|c|c|}
\hline \multicolumn{1}{|c|}{ Variabl } & Model 1 & Model 2 & Model 3 \\
\hline & Jarque-Ber & Jarque-Ber & Jarque-Ber \\
& $\mathrm{a}$ & $\mathrm{a}$ & $\mathrm{a}$ \\
\hline BOP & 279.1251 & 7882.922 & 882.6981 \\
\hline CD & 65.26563 & 8.056713 & 23.75000 \\
\hline PIT & 191.1046 & 1.437152 & 76261.10 \\
\hline UNEM & 4.132547 & 5.794909 & 5.794909 \\
\hline VAT & 1914.466 & 1.910047 & 35.30803 \\
\hline GDP & 3.937433 & 1260.104 & 12.09695 \\
\hline
\end{tabular}

The descriptive stats give a researcher an idea of the type of data they are using at a glance. From the table above, the researcher focused on the JB of the data set to determine whether they are normally distributed or not. The JB shows that in model 1, UNEM and GDP are normally distributed; in model II, VAT, PIT and CD are normally distributed while in model III, CD, UNEM and GDP are normally distributed.

\section{Unit Root Tests}

The ADF is used to test for the presence of random walk among the variables used. The unit root tests for the presence of stationarity. The table below shows the test results at levels and at second difference. The results reveal that the variables are stationary at second difference.

Source: Eviews test results

\begin{tabular}{|c|c|c|c|}
\hline Coefficient & $\mathrm{I}(0)$ & $\mathrm{I}(1)$ & Comment \\
\hline $\begin{array}{l}\text { BOP (At levels: prob }=0.0000) \\
(\text { At I }(1): \text { prob }=0.0000\end{array}$ & Stationary & $\mathrm{NA}$ & \\
\hline $\begin{array}{l}\text { CD (At levels: prob }=0.7689) \\
\text { (At I(1): prob }=0.0000\end{array}$ & Nonstationary & Stationary & \\
\hline $\begin{array}{l}\text { GDP (At levels: prob }=0.0000) \\
\text { (At I(1): prob }=0.0009\end{array}$ & Stationary & NA & \\
\hline $\begin{array}{l}\text { PIT (At levels: prob }=1.0000)(\text { At } \\
\text { I(1): prob }=0.0000\end{array}$ & Nonstationary & Stationary & \\
\hline $\begin{array}{l}\text { UNEM (At levels: prob }=0.6813 \text { ) } \\
\text { (At I }(1): \text { prob }=0.0000\end{array}$ & Nonstationary & Stationary & \\
\hline $\begin{array}{l}\text { VAT (At levels: prob }=1.0000) \\
(\text { At I }(1): \text { prob }=0.0000\end{array}$ & Nonstationary & $\mathrm{NA}$ & \\
\hline
\end{tabular}

\section{Source: Eviews results}

\section{Bounds Test}

In order to determine whether the variables are co-integrated or not, and with the mixture of at levels and first differencing unit roots, a bounds test for co-integration must be conducted. Co-integration shows if there is a long-run relationship or not. The bounds tests for the three models shows that there is a long run relationship among the variables used.

The presence of a co-integrating factor becomes the basis for the conduct of error correction model.

\section{Model I}

F-Bounds Test

Null Hypothesis: No levels relationship

\begin{tabular}{lclcc}
\hline \hline Test Statistic & Value & Signif. & $\mathrm{I}(0)$ & $\mathrm{I}(1)$ \\
\hline \hline & & \multicolumn{3}{c}{ Asymptotic: } \\
& & & $\mathrm{n}=1000$ \\
F-statistic & 26.61160 & $10 \%$ & 3.8 & 3.8 \\
$\mathrm{k}$ & 0 & $5 \%$ & 4.6 & 4.6 \\
& & $2.5 \%$ & 5.39 & 5.39 \\
& & $1 \%$ & 6.44 & 6.44
\end{tabular}

Source: Eviews test results 


\section{Model II}

F-Bounds Test

Null Hypothesis: No levels relationship

\begin{tabular}{lllll}
\hline \hline Test Statistic & Value & Signif. & $\mathrm{I}(0)$ & $\mathrm{I}(1)$ \\
\hline \hline & & \multicolumn{3}{c}{$\begin{array}{c}\text { Asymptotic: } \\
\mathrm{n}=1000\end{array}$} \\
F-statistic & 7.307931 & $10 \%$ & 2.72 & 3.77 \\
$\mathrm{k}$ & 3 & $5 \%$ & 3.23 & 4.35 \\
& & $2.5 \%$ & 3.69 & 4.89 \\
& & $1 \%$ & 4.29 & 5.61
\end{tabular}

Source: Eviews test results

\section{Model III}

\begin{tabular}{lllll} 
F-Bounds Test & & \multicolumn{3}{c}{ Null Hypothesis: No levels relationship } \\
\hline \hline Test Statistic & Value & Signif. & $\mathrm{I}(0)$ & $\mathrm{I}(1)$ \\
\hline \hline \multirow{2}{*}{ F-statistic } & & \multicolumn{3}{c}{ Asymptotic: } \\
k & \multirow{3}{*}{$\mathrm{n}=1000$} \\
& 3.09804 & $10 \%$ & 2.72 & 3.77 \\
& & $5 \%$ & 3.23 & 4.35 \\
& & $2.5 \%$ & 3.69 & 4.89 \\
& $1 \%$ & 4.29 & 5.61
\end{tabular}

Source: Eviews test results

\section{Granger Causality Test}

\section{Model I}

The pair-wise granger causality test shows the direction of cause between the dependent and the independent variables. The table below shows that there is a bidirectional causality between GDP and CD. Also, there unidirectional causality between GDP, VAT while there is no causality between GDP and PIT. This is shown below:

Pairwise Granger Causality Tests

Date: : 11/08/19 Time: 00:03

Sample: 19802018

Lags: 2

\begin{tabular}{|c|c|c|c|}
\hline \multirow[b]{2}{*}{ Null Hypothesis: } & \multicolumn{3}{|c|}{ F-Statisti } \\
\hline & Obs & $\mathrm{c}$ & Prob. \\
\hline CD does not Granger Cause GDP & 36 & 5.24071 & 0.0109 \\
\hline GDP does not Granger Cause CD & & 5.38421 & 0.0098 \\
\hline PIT does not Granger Cause GDP & 36 & 1.59277 & 0.2196 \\
\hline GDP does not Granger Cause PIT & & 1.29921 & 0.2872 \\
\hline VAT does not Granger Cause GDP & 36 & 13.9526 & 5.E-05 \\
\hline GDP does not Granger Cause PIT & & 1.23259 & 0.3054 \\
\hline
\end{tabular}

\section{Source: Eviews test results}

\section{Model II}

Pairwise Granger Causality Tests

Date: : 11/08/19 Time: 00:07

Sample: 19802018

Lags: 2

\begin{tabular}{lcccc}
\hline \hline & \multicolumn{3}{c}{ F-Statisti } \\
Null Hypothesis: & Obs & c & Prob. \\
\hline \hline CD does not Granger Cause BOP & \multirow{2}{*}{36} & & 6.21101 & 0.0012 \\
BOP does not Granger Cause CD & & & 2.73421 & 0.0022
\end{tabular}


Trade Tariffs and Selected Macroeconomic Indicators of Performance in Nigeria, 1980 - 2018

\begin{tabular}{lrrr}
\hline \hline PIT does not Granger Cause BOP & 36 & $\begin{array}{l}3.01277 \\
1.04322\end{array}$ & 0.0041 \\
BOP does not Granger Cause PIT & 4 & 0.8372 \\
\hline \hline VAT does not Granger Cause BOP & 36 & $\begin{array}{l}7.19731 \\
2.94411\end{array}$ & $\begin{array}{l}0.0935 \\
0.0052\end{array}$ \\
BOP does not Granger Cause PIT & $=$
\end{tabular}

Source: Eview test results

Model III

Pairwise Granger Causality Tests

Date: : 11/08/19 Time: 00:09

Sample: 19802018

Lags: 2

\begin{tabular}{lcccc}
\hline \hline & & \multicolumn{2}{c}{ F-Statisti } & \\
Null Hypothesis: & Obs & c & Prob. \\
\hline \hline CD does not Granger Cause UNEM & 36 & 5.28311 & 0.0109 \\
UNEM does not Granger Cause CD & & 1.01121 & 4.1338 \\
\hline \hline PIT does not Granger Cause UNEM & \multirow{2}{*}{36} & 8.56377 & 0.0453 \\
UNEM does not Granger Cause PIT & & 1.71221 & 0.8772 \\
\hline \hline VAT does not Granger Cause UNEM & \multirow{2}{*}{36} & & 6.19526 & 6.7325 \\
UNEM does not Granger Cause PIT & & 1.27659 & 0.8122 \\
\hline \hline
\end{tabular}

Source: Eview test results

Error Correction Mechanism

Error Correction Model I (BOP)

\begin{tabular}{|l|l|l|l|}
\hline Variables & Coefficients & Std Error & t-Stat \\
\hline PIT & 54.09046 & 192.9621 & 0.280317 \\
\hline CD & 0.057042 & 0.288278 & 0.197871 \\
\hline VAT & 80.55517 & 402.6432 & 0.200066 \\
\hline C & 2242.612 & 2451.866 & 0.914655 \\
\hline R-Square & 0.097559 & & \\
\hline F-Stat & 0.259454 & & \\
\hline DW & 2.226861 & & \\
\hline ECM & -0.290052 & 0.195247 & -1.485567 \\
\hline
\end{tabular}

Source: Eviews test results

Error Correction Model II (GDP)

\begin{tabular}{|l|l|l|l|}
\hline Variables & Coefficients & Std Error & t-Stat \\
\hline PIT & 22.96548 & 9.835173 & 2.335036 \\
\hline CD & 0.129170 & 0.118404 & 1.090930 \\
\hline VAT & -0.513604 & 0.295544 & -1.737824 \\
\hline C & 2242.612 & 2451.866 & 0.914655 \\
\hline R-Square & 0.934813 & & \\
\hline F-Stat & 34.41699 & & \\
\hline DW & 2.017108 & & \\
\hline ECM & -0.108528 & 0.310612 & -0.349402 \\
\hline
\end{tabular}

Source: Eviews test results

Error Correction Model III (UNEM)

\begin{tabular}{|l|l|l|l|}
\hline Variables & Coefficients & Std Error & t-Stat \\
\hline PIT & 22.96548 & 9.835173 & 2.335036 \\
\hline CD & $-4.04 \mathrm{E}-06$ & $3.77 \mathrm{E}-05$ & -0.107008 \\
\hline VAT & 0.182688 & 0.058703 & 3.112093 \\
\hline C & 6.090434 & 0.937167 & 6.498774 \\
\hline R-Square & 0.746098 & & \\
\hline
\end{tabular}




\begin{tabular}{|l|l|l|l|}
\hline F-Stat & 7.052457 & & \\
\hline DW & 1.481585 & & \\
\hline ECM & 0.557810 & 0.231224 & 2.412418 \\
\hline
\end{tabular}

Source: Eviews test results

The long-run ECM analysis shows that the coefficient of determination are model $\mathrm{I}=0.09$, model $\mathrm{II}=0.93$ and model III $=0.74$. This means that $9 \%, 93 \%$ and $74 \%$ of the changes in the dependent variables of the models are explained by the changes in the independent variables. The overall model I $=0.25 ;$ model II $=34.4$; and model III $=7.05$ are also statistically significant at $5 \%$ level of significance, except for model I. We also note that the ECM is rightly signed as it shows that the speed of adjustment is $29 \%, 11 \%$ and $56 \%$ respectively. Models I and II are not statistically significant while model III is statistically significant at 5\% level of significance.

\section{Serial correlations}

The researcher used the serial correlation test to know if there is the existence of serial autocorrelation or not among the variables. The result shows that there is absence of serial autocorrelation.

Model I (GDP)

Breusch-Godfrey Serial Correlation LM Test:

\begin{tabular}{cccc}
\hline \hline $\begin{array}{c}\text { F-statistic } \\
\text { Obs*R-squared }\end{array}$ & $\begin{array}{c}0.806842 \\
\text { P.617272 }\end{array}$ & $\begin{array}{c}\text { Prob. F(3,21) } \\
\text { Prob. Chi-Square(3) }\end{array}$ & $\begin{array}{c}0.5042 \\
0.3059\end{array}$ \\
\hline \hline & $\begin{array}{c}\text { Source: Eviews test results } \\
\text { Model II (BOP) }\end{array}$ \\
Breusch-Godfrey Serial Correlation LM Test: & 0.7882 \\
\hline \hline F-statistic & $\begin{array}{l}0.902242 \\
\text { Obs*R-squared }\end{array}$ & Prob. F(3,21) & 0.3059 \\
\hline \hline & Source: Eviews test results & \\
Breusch-Godfrey Serial Correlation LM Test: & 0.0016 \\
F-statistic & 7.283300 & Prob. F(3,21) \\
Obs*R-squared & 17.84710 & Prob. Chi-Square(3) & 0.0005 \\
\hline \hline
\end{tabular}

Source: Eviews test results

\section{Heteroskedasticity Test}

Heteroskedasticity Test (GDP)

Heteroskedasticity Test: Breusch-Pagan-Godfrey

\begin{tabular}{cccc}
\hline \hline F-statistic & 2.477165 & Prob. F(10,24) & 0.0334 \\
Obs*R-squared & 17.77688 & Prob. Chi-Square(10) & 0.0588 \\
Scaled explained SS & 14.94166 & Prob. Chi-Square(10) & 0.1342 \\
\hline \hline
\end{tabular}

Source: Eviews test results

Heteroskedasticity Test (UNEM)

Heteroskedasticity Test: Breusch-Pagan-Godfrey

\begin{tabular}{cccc}
\hline \hline F-statistic & 1.382321 & Prob. F(10,24) & 0.2468 \\
Obs*R-squared & 12.79141 & Prob. Chi-Square(10) & 0.2356 \\
Scaled explained SS & 8.304058 & Prob. Chi-Square(10) & 0.5992 \\
\hline \hline
\end{tabular}

Source: Eviews test results

Heteroskedasticity Test (BOP)

Heteroskedasticity Test: Breusch-Pagan-Godfrey

\begin{tabular}{cccc}
\hline \hline F-statistic & 1.382321 & Prob. F(10,24) & 0.2468 \\
Obs*R-squared & 12.79141 & Prob. Chi-Square(10) & 0.2356 \\
Scaled explained SS & 8.304058 & Prob. Chi-Square(10) & 0.5992 \\
\hline \hline
\end{tabular}

Source: Eviews test results 
The variances of the models are not also constant based on the results of the heteroskedasticity test. This is the result of $\mathrm{GDP}=\mathrm{f}(\mathrm{VAT}, \mathrm{CD}, \mathrm{PIT})$.

\section{B. Tests of Hypotheses}

\section{$\mathbf{H}_{01}$ : Balance of Payments and Custom Duty}

The result of the analysis shows that custom duty is positively related to balance of payment as expected apriori. The result reveals that as customs duty (CD) increases by a unit, balance of payments (BOP) increases by 0.057042 units and vice versa. However, custom duty is statistically insignificant at $5 \%$ level of significance using the t-value. The analysis shows that we will reject the alternative hypotheses and conclude that there is no significant relationship between custom duty and balance of payments over the period under investigation.

\section{$\mathrm{H}_{02}$ : Balance of Payments and Petroleum Income Tax}

The result above reveals that petroleum income tax (PIT) also has a positive relationship with balance of payments (BOP). As PIT decreases over the period by a unit, BOP decreases by 54.09046 units and vice versa. PIT is also statistically insignificant at 5\% level. We would reject the alternative hypotheses, accept the null hypotheses and conclude that there is no significant relationship between petroleum income tax and balance of payments over the period studied.

The above analysis shows that petroleum income tax does have pleasant but insignificant relationship with balance of payments (especially, in the case of Nigeria). It seems that despite the quantity of crude oil exported by the major oil multinationals, the income from petroleum tax has not been a major part of the balance of payments over the period.

$\mathrm{H}_{03}$ : Balance of Payments and Value Added Tax

The result above also shows that value added tax (VAT) has a positive relationship with balance of payments (BOP). As VAT increases over the period by a unit, BOP increases by 80.55517 units and vice versa. VAT, however, is not statistically significant at 5\% level according to the t-value (0.2). We would reject the alternative hypotheses, accept the null hypotheses and conclude that there is no significant relationship between value added tax and balance of payments over the period.

\section{$\mathrm{H}_{04}$ : Gross Domestic Products and Custom Duty}

The result of the analysis shows that custom duty (CD) is positively related to gross domestic product (GDP) as expected apriori. The result reveals that as customs duty (CD) increases by a unit, GDP increases by 0.12 units and vice versa. However, CD is statistically insignificant at $5 \%$ level of significance using the t-value. The analysis shows that we will reject the alternative hypotheses and conclude that there is no significant relationship between custom duty and gross domestic products over the period.

\section{$\mathrm{H}_{05}$ : Gross Domestic Products and Petroleum Income Tax}

The result above reveals that petroleum income tax (PIT) also has a positive relationship with gross domestic products (GDP). As PIT increases over the period by a unit, GDP increases by 22.95 units and vice versa. PIT is statistically significant at 5\% level. We would accept the alternative hypotheses, reject the null hypotheses and conclude that there is a significant relationship between petroleum income tax (PIT) and gross domestic products (GDP) over the period.

\section{$\mathrm{H}_{06}$ : Gross Domestic Products and Value Added Tax}

The result above also shows that value added tax (VAT) has a negative relationship with gross domestic products (GDP). As VAT increases over the period by a unit, GDP decreases by 0.5 units and vice versa. VAT, however, is not statistically significant at 5\% level according to the t-value (1.7). We would reject the alternative hypotheses, accept the null hypotheses and conclude that there is no significant relationship between value added tax and gross domestic products over the period.

\section{$\mathrm{H}_{07}$ : UnemploymentRate and Custom Duty}

The result of the analysis shows that custom duty (CD) is natively related to unemployment rate (UNEM) as expected apriori. The result reveals that as customs duty (CD) decreases by a unit, UNEM increases by -4.04 units and vice versa. Again, $C D$ is statistically insignificant at $5 \%$ level of significance using the t-value. The analysis shows that we will reject the alternative hypotheses and conclude that there is no significant relationship between custom duty (CD) and unemployment (UNEM) over the period.

The relationship between unemployment and customs duty becomes deep when the customs duty is not regulated. Increased customs duty reduces importation of capital goods used for further investments and this ultimately increases unemployment rate over the period.

\section{$\mathbf{H}_{08}$ : UnemploymentRate and Petroleum Income Tax}

The result above reveals that petroleum income tax (PIT) also has a positive relationship with unemployment rate (UNEM). As PIT increases over the period by a unit, UNEM increases by 22.96 units and vice versa. PIT is also statistically significant at $5 \%$ level. We would accept the alternative hypotheses, reject the null hypotheses and conclude that there is a significant relationship between petroleum income tax (PIT) and unemployment (UNEM0 over the period.

The expected relationship was negative however. Increment in petroleum income tax adds to the general cost of production for the major oil exporters and as a result, funds earmarked for reinvestments will be reduced. This has a major effect on the unemployment rate in the long run and short runs.

\section{$\mathrm{H}_{09}$ : Unemployment Rate and Value Added Tax}

The result above also shows that value added tax (VAT) has a positive relationship with unemployment rate (UNEM). As VAT increases over the period by a unit, UNEM increases by 0.18 units and vice versa. VAT, however, is statistically significant at $5 \%$ level according to the t-value (3.1). We would accept the alternative hypotheses, reject the null hypotheses and conclude that there is a significant relationship between value added tax and unemployment rate over the period.

\section{Discussion of the Findings}

The researcher investigated and analysed the relationship betweentrade tariffs and economic development of Nigeria, 1980 - 2018 using the Auto-Regressive Distributed Lag 
Models and Error Correction Mechanism (ECM). The researcher used gross domestic products (GDP), balance of payments (BOP0 and unemployment rate (UNEM) as dependent variables for the models while value added tax (VAT), custom duty (CD) and petroleum income tax (PIT) were used as the independent variables to capture the incidences of economic growth and development.

The analysis found that there is a positive but insignificant relationship between balance of payment and customs duty. Customs duty is a source of income for the government. Customs duties, as made up of export and import duties, are compulsory payments made on exported or imported products through the Nigerian borders. The insignificant relationship between balance of payments (BOP) and custom duty (CD) shows that there is no direct relationship between the two variables. Increase or decrease custom duty will only affect the balance of payments depending on the aim of the government. Increase in import duties gives the local manufacturers an edge and therefore, reduces the deficits in the balance of payments over time while increase in export duties has the opposite effect on the BOP. With the increase in petroleum income tax (PIT), BOP is reduced while the opposite will have an increased BOP. The analysis shows that PIT has an insignificant relationship with BOP even though they have positive relationship. Just like the PIT, the VAT has positive but insignificant relationship with BOP. These findings agree with the findings of Osman and Evans (2005) and Nadeesha and Silva (2013). These authors, who investigated in different areas using related parameters and variables, agree that import duties have a positive and significant relationship with the BOP.

Further, the analysis shows that customs duty has positive and significant relationship with the gross domestic product (GDP) over the period. As pointed out earlier, the custom duty (CD) is a source of income for the government and a well-harnessed custom duty will add to the coffers of the government. This finding also agrees with the findings of Zheng and Sayed (2012). Also, the analysis states that petroleum income tax (PIT) and GDP have positive and significant relationship. Therefore, more PIT ensures more GDP and vice versa. Being part of the ways the government raise funds, it is seen that PIT add to the GDP, although, the same PIT has a negative relationship with the UNEM and that ultimately reduces the GDP over time. More so, the analysis reveals that value added tax (VAT), another major source of income, actually has a negative relationship with gross domestic products (GDP). Increased tax rate reduces the aggregate demand (at least, in the short run) and a reduced aggregate demand results to reduced GDP. Woerter and Roper (2010) pointed this out when they investigated the export relationship with manufacturing of 73 countries using panel data. They found that value added tax (VAT) also has a negative relationship with the gross domestic products (GDP) over the period.

In the above research study, one of the key ways of measuring economic development is with the unemployment rate. Regressing the independent variables against the unemployment rate, the researcher found that custom duty (CD) and unemployment (UNEM) are negatively related.
Increased CD adds to the seller's costs and indirectly reduces income generated and funds for reinvestments that could create jobs. Equally, the results of the relationship between UNEM and PIT revealed that there is a positive relationship, unlike with custom duty. Although, the expected relationship was negative because Increase in petroleum income tax (PIT) adds to the general cost of production for the major oil exporters and as a result, funds set out for reinvestments will be reduced. This has a major effect on the unemployment rate in the long run and short runs. Finally, the analysis on unemployment rate (UNEM) and value added tax(VAT) shows that there is a positive and significant relationship between UNEM and VAT. Zheng and Sayed (2012) and Woerter and Roper (2010) arrived at the same answer having carried out their studies in different countries and at different times.

\section{CONCLUSION AND RECOMMENDATIONS}

Even though there are many studies on trade tariffs and macroeconomic indicators, past empirical studies didn't use the ARDL analytical technique to measure the impact. In fact, no no-three-model studies have been undertaken using the three dependent variables over the period. This study expanded the existing literatures on the trade tariffs and macroeconomic indicators (economic development) by using the ARDL model in the analysis. This study was motivated by the need to avoid parameter bias arising from possible model misspecification as well as the need to re-examine the impact of trade tariffs on the economic developments in Nigeria. Using annual time series data, the researcher examined the short- and long-run relationships between the dependent and the independent variables.

The heteroscedasticity shows that the variances for the variables have been constant over time while the normality test shows an evidence to reject the null hypothesis. The serial LM correlation showed that there is absence of autocorrelation of the first order among the variables while the bounds test for co-integration confirmed that there is a long-run relationship among the variables. ECM appropriately corrected these in the short run.

Therefore, it is recommended that for customs duty to be useful in economic development, it has to be well-managed by the monetary authorities. There is need to properly target tariffs so as to achieve a particular aim and not to increase it indiscriminately without knowing the impact it will have on the general populace. This also applies to value added tax (VAT) and petroleum income tax (PIT) as they also significantly impact on the unemployment rate and balance of payments in Nigeria.

\section{REFERENCES}

[1] Adamu, P.A. (2005). Globalization and the challenge for the Nigeria economy. Knowledge Review, 11(2).

[2] Ajayi, S.I. (2001). What Africa needs to do to benefit from globalization. IMF Finance and Development, 38(4), 6.

[3] Ajayi, S.I. (2003). Globalization and Africa. Journal of Africa Economies, 12(1).

[4] Alege P.O. (2006). Impact of globalization on employment in the Nigerian economy. Paper presented at the 47th Annual Conference of the Nigerian Economic Society.

[5] Artis, M.J.,\& Okubo, T. (2008). Globalization and business cycle transmission. CEPR Discussion Paper 7041. 
[6] Asekunowo, V.O. (2004). What economic gains has Nigeria recorded from globalization so far? International Journal of Business and Common Market Studies, 2(1\&2) Development Universal Consortia.

[7] Bahmani-Oskoee, M.,\& Niroomand, F. (1998). Long-run price elasticities and the Marshall-Lerner condition revisited. Economics Letters, 61, 101-109.

[8] Bairoch, P.,\& Kozul-Wright, R. (1996). Globalization myths: Some historical reflections on integration, industrialization and growth in the world economy. UNCTAD DP, NO. 113.

[9] Brüggemann, A., Donati, P.,\& Warne, A. (2003). Is the demand for euro area M3 stable?. European Central Bank Working Paper, No. 255.

[10] Calamitsis, E.A. (2001). The need for stranger domestic policies and international support. IMF Finance and Development, 38(4), 10-12.

[11] Central Bank of Nigeria Statistical Bulletin 2013, Volume 24.

[12] Dike, J. (2013). Measuring the security of energy exports demand in OPEC economies. Energy Policy, 60, 594-600.

[13] Ekeocha, P.C.,\& Williams, O.E. (2006). Globalization and employment generation: evaluating the impact of trade on aggregate employment in Nigeria's industrial sector.

[14] Hamori, S.,\& Matsubayashi, Y. (2009). Empirical analysis of export demand behavior of LDCS: Panel cointegration approach. MPRA paper, 17316, pp. 1-12.

[15] Hossain, A. (2009). Structural change in the export demand function for Indonesia: Estimation, analysis and policy implications. Journal of Policy Modeling, 31, 260-271.

[16] Husein, J. (2007). Export-led growth hypothesis: A multivariate cointegration and causality evidence for Jordan, Journal of Developing Areas, 42(2) (forthcoming).

[17] Husein, J. (2008). Traditional export demand relation: A cointegration and parameter constancy analysis. International Journal of Applied Econometrics and Quantitative Studies, 5(2), 41-65.

[18] Khor, M. (2005). Globalization and the South: Some critical issues Spectrum Books Limited, Ibadan.

[19] Lipsey, R.G.,\& Chrystal, K.A. (2005). Principle of economics, 9th Edition, Oxford Press.

[20] Los, B., Timmer, M.,\& Vries, G. (2015). How important are exports for job growth in China?. A demand side analysis. Journal of Comparative Economics, 43, 19-32.

[21] Maku, O.E. (2007). Globalization and economic development in Sub-Saharan Africa (SSA) countries. Journal of Economic and Management Sciences, 1(2).

[22] McConnel, C.R.,\& Brue, S.L. (2002). Economics; Principles, Problems and Policies. Mc Graw-Hill Irwin.

[23] Nadeesha, D.,\& Silva, A. (2013). A time-series analysis of export-led shipping demand hypothesis for Sri Lanka. International Journal of Scientific and Research Publications, 3(9), 1-6.

[24] Nanang, D. (2010). Analysis of export demand for Ghana's timber products: A multivariate co-integration approach. Journal of Forest Economics, 16, 47-61.

[25] Onyeonoru, I. (2003). Globalization and industrial performance in Nigeria. Africa Development, 38 (3 \& 4), 36-66.

[26] O’Rourke, K.,\& Williamson, J.C. (2006). When did globalization begin?. NBER Working Paper, 7632.

[27] Osman, M.,\& Evans, S. (2005). Time series analysis of the Somalian export demand equations: a co-integration approach. Journal of Economic and Social Research, 4(2), pp. 71-92.

[28] Oviemumo, A.O. (2007). International trade as an engine of growth in developing countries: A case study of Nigeria (1980-2003). http://searchwarp.com.

[29] Scholfe, J.A. (2000). Globalization: A critical introduction. Houndmills: Macmillian Press.

[30] Senhadji, A.,\& Montenegro, C. (1999). Time Series Analysis of Export Demand Equations: A Cross-Country Analysis. IMF Staff Papers, 46(3), 259-723.

[31] Usman, S. (1999). Implications of globalisation for the Nigeria economy: Globalization and Nigeria's economy development.

[32] Woerter, M.,\& Roper, S. (2010). Openness and innovation-Home and export demand effects on manufacturing innovation: Panel data evidence for Ireland and Switzerland. Research Policy, 39,155-164.

[33] Zheng, Z.,\& Sayed, S. (2012). Time-series analysis of U.S. Pistachio export demand in North America. Journal of Food Distribution Research, 42(1), 124-129. 